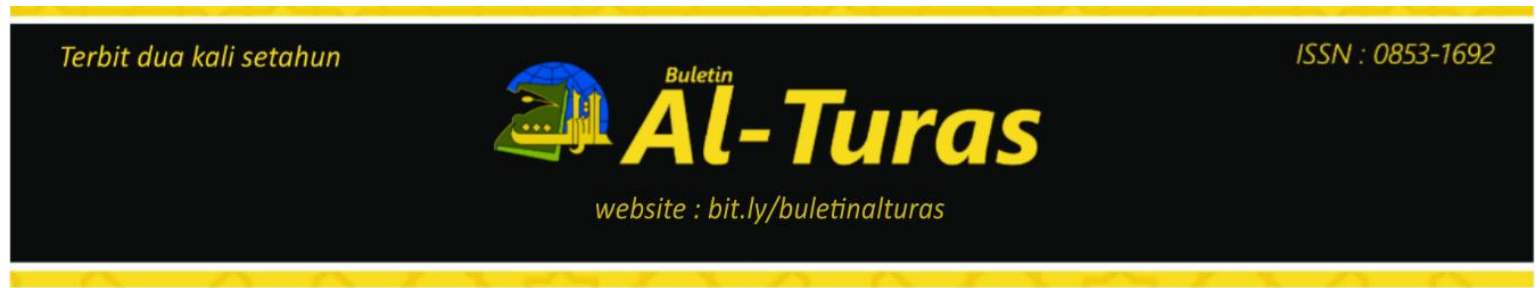

\title{
Konjungsi Koordinatif Bahasa Jepang dalam Biografi Helen Keller, Esai Real Japanese, dan Kumpulan Cerpen Dondon Yomeru Hanashi
}

\author{
Ruli Oknita Sari \\ Universitas Andalas \\ Padang, Indonesia \\ rulisari427@gmail.com
}

\author{
M.Yusdi \\ Universitas Andalas \\ Padang, Indonesia \\ muhammad_yusdi@yahoo.co.id
}

\author{
Gusdi Sastra \\ Universitas Andalas \\ Padang, Indonesia \\ sastrabudaya84@gmail.com
}

\begin{abstract}
Abstrak
Konjungsi merupakan kelas kata yang ada pada setiap bahasa. Penelitian ini bertujuan mendeskripsikan perilaku sintaksis konjungsi koordinatif bahasa Jepang. Perilaku sintaksis tersebut meliputi fungsi konjungsi, letak struktural konjungsi, dan sifat kehadiran konjungsi. Sumber data penelitian ini yaitu Biografi Hellen Keller, Esai Read Real Japanese, dan kumpulan Cerpen DonDon Yomeru IriIro Na Hanashi. Penelitian ini merupakan penelitian kualitatif yang bersifat deskriptif. Dalam menganalisis data peneliti menggunakan metode padan translasional untuk pemindahan arti dari bahasa Jepang ke bahasa Indonesia. Untuk menganalisis fungsi konjungsi, letak struktural konjungsi, dan sifat kehadiran konjungsi peneliti menggunakan metode distribusional beserta tekniknnya. Hasil analisis data menunjukan bahwa fungsi konjungsi koordinatif bahasa Jepang yaitu menghubungkan kata dengan kata yaitu konjungsi to dan konjungsi ya, dan menghubungkan klausa dengan kluasa yaitu konjungsi ga dan konjungsi -shi. Letak struktural konjungsi koordinatif bahasa Jepang yaitu berada di antara unsur yang digabungkan. Sementara itu, sifat kehadiran konjungsi di dalam konstruksi adalah wajib dan tidak dapat dilesapkan.
\end{abstract}

Kata kunci: konjungsi koordinatif; aditif; kontradiktif; klausa

\section{Abstract}

Conjunction is a class of words that exist in every language. This study aims to describe the syntactic behavior of Japanese coordinating conjunctions. The syntactic behavior includes the function of the conjunction, the structural location of the conjunction, and the presence of the conjunction. The data sources of this research are Hellen Keller Biography, Real Japanese Read Essays, and a collection of Dondon Yomeru Hanashi short stories. This research is a descriptive qualitative research. In analyzing the data the researcher applies the translational equivalent method for the transfer of meaning from Japanese to Indonesian. To analyze the function of the conjunction, the structural location of the conjunction, and the nature of the presence of the conjunction, the researcher uses the distributional method and its technique. The results of data analysis show that the coordinating conjunctions of Japanese are linking words to words, namely conjunctions to and conjunctions ya and linking clauses with clauses, which is conjunctions ga and conjunctions -shi. The structural position of Japanese coordinating conjunctions is among the elements combined. Meanwhile, the presence of conjunctions in construction is mandatory and cannot be mitigated.

Keywords: coordinative conjunction; additive; condtradictive; clause 


\section{A. Pendahuluan}

Bahasa merupakan salah satu anugrah yang diberikan oleh Tuhan kepada manusia. Manusia adalah makhluk yang berfikir dan berkomunikasi melalui bahasa. Bahkan wahyu dari Tuhan sekalipun diturunkan melalui bahasa. Bahasa mempunyai peranan penting dalam kehidupan umat manusia. Tidak dapat dibayangkan bagaimana jadinya kehidupan manusia tanpa adanya bahasa.

Kesadaran akan pentingnnya bahasa menjadikan banyaknya orang tertarik mengkaji persoalan bahasa. Jika dilihat dari sejarahnya, tokoh awal yang dikenal menelaah bahasa yaitu Aristoteles dan Plato. Bahkan para ahli sejarah linguistik sepakat bahwa dasar-dasar konsepsi kelas kata diletakan oleh Plato dan Aristoteles.

Jika dilihat dari jumlahnya ada banyak sekali bahasa di dunia. Sejak zaman aristoteles hingga saat sekarang ini bahasa merupakan kajian yang menarik dan masih belum selesai ditelaah. Salah satu kajian yang sudah mulai ditelaah semenjak zaman Aristoteles yaitu mengenai kategori kata atau kelas kata. Bahkan studi mengenai kelas kata menempati posisi yang penting di Eropa pada mula perkembanganya.

Terdapat berbagai cara dan teori yang digunakan oleh para ahli linguistik atau ahli bahasa dalam menganalisis kelas kata. Makin berkembangannya penelitian mengenai bahasa maka teori-teori dan metode-metode dalam menganalisis dan mendeskripsikan kelas kata semakin mengalami peningkatan.

Kriteria dari pembagian kelas kata dilakukan secara gramatikal dan bukan semantik $^{1}$. Akan tetapi, kaum tradisional biasanya membagi kelas kata berdasarkan

\footnotetext{
${ }^{1}$ Tymothi (Ed) Sophen, Typologi and Sintactic Description: Volume 1, Clause Structure (New York: Cambridge University Press, 2007).

${ }^{2}$ Ida Ayu Mirah Purwiati, "Konjungsi Subodinatif Dalam Teks Buku Pelajaran SLTA: Analisis Bentuk, Distribusi, Dan Makna," Aksara 27, no. 2 (Desember 2015): 133-50.
}

makna dan fungsi sebuah kata. Sementara itu kaum struktualis membagi kelas kata berdasarkan distribusinya di dalam sebuah konstruksi. Dalam sistem pembagian kelas atau part of speech, terdapat kategori kata yang disebut dengan konjungsi. Konjungsi termasuk salah satu kata noneferensial, yakni kata yang tidak mempunyai acuan di luar ahasa ${ }^{2}$.

Setiap bahasa-bahasa di dunia memiliki suatu kecendrungan atau universal tendency. Kecendrungan tersebut terlihat pada pembagian kelas katannya. Setiap bahasa di dunia memiliki kelas kata yang disebut dengan konjungsi. Di dalam bahasa Jepang juga ditemukan kelas kata atau kata yang bertugas sebagai konjungsi.

Bahasa Jepang merupakan bahasa ynag dipakai sebagai alat komunikasi oleh masyarakat jepang. Bahasa Jepang dipakai sebagai bahasa resmi dan sebagai bahasa pengantar di semua Lembaga Pendidikan Jepang.

Dalam Bahasa Jepang terdapat istilah setsuzokushi dan setsuzokujhosi. Setsuzokushi merupakan istilah yang digunakan untuk menyebutkan konjungsi dalam bahasa Jepang, sedangkan setsuzokujoshi adalah konjungsi bahasa Jepang yang berasal dari kelas kata partikel. Menurut Setiana ${ }^{4}$ konjungsi/setsuzokushi dalam Bahasa Jepang merupakan salah satu jenis kata yang penting, sulit untuk dipelajari, dan jumlahnnya sangat banyak.

Apabila kita merujuk kepada kebanyakan buku-buku gramatika bahasa Jepang yang terbit di Indonesia kedua kelas kata ini dibedakan meskipun tugasnnya sama. Namun di dalam penelitian ini peneliti tidak menggunakan

\footnotetext{
${ }^{3}$ Song J.J, "Linguistic Typology : Morphology and Syntac" (England: Pearson Education Limited, 2001).

${ }^{4}$ Soni Mulyawan Setiana, "Fungsi Dan Penggunaan Setsuzokushi (Sorede, Sokode, Dan Suruto)," Majalah Ilmiah UNIKOM 10, no. 2 (2012).
} 
istilah setzuzokushi ataupun setsuzokujoshi untuk merujuk kepada konjungsi Bahasa Jepang. Karena baik itu setsuzokushi dan setsuzokujoshi keduannya merujuk kepada hal yang sama yaitu suatu konstituen atau kata yang digunakan untuk menghubungkan unit gramatikal di dalam Bahasa Jepang. Meskipun dalam tata bahasa Jepang kedua kelas kata ini dibedakan namun pada prinsipnnya kedua kelas kata ini memiliki fungsi dan tugas yang sama.

Menurut Sophen ${ }^{5}$ konjungsi merupakan kata yang digunakan untuk menghubungkan satuan lingual seperti kata, frasa, dan klausa. Alwi ${ }^{6}$ menggunakan istilah konjungtor dan bukan konjungsi untuk merujuk kepada kelas yang berfungsi menghubungkan satuan lingual. Menurutnya, kojungtor atau kata sambung merupakan kata yang masuk ke dalam kelas kata tugas yaitu kelas kata yang tidak memiliki makna leksikal namun hanya memiliki makna gramatikal. Menurut Kridalaksana ${ }^{7}$ konjungsi merupaka konstruksi yang dapat meluaskan satuan yang lain dalam konstruksi hipotakstis, dan selalu menghubungkan dua satuan lain atau lebih dalam satu konstruksi. Konstruksi hipotakstis yang dimaksud di sini yaitu konstruksi yang digabungkan dengan menggunakan konjungsi atau penghubung sedangkan lawan dari satuan hipotaksis yaitu satuan parataksis dimana satuan lingual digabungkan tidak menggunakan konjungsi akan tetapi menggunakan jeda atau koma. Pada umumnnya konstruksi parataksis dan hipotaksis merujuk kepada konstruksi kalimat majemuk. Pada konstruksi kalimat majemuk satuan lingual berupa klausa dapat dihubungkan dengan menggunakan hubungan yang hipotaksis yaitu menggunakan konjungsi,

\footnotetext{
${ }^{5}$ Sophen, Typologi and Sintactic Description:

Volume 1, Clause Structure.

${ }^{6} \mathrm{dkk}$. Alwi, Tata Bahasa Baku Indonesia

(Jakarta: Balai Pustaka, 1998).
}

atau melalui hubungan yang parataksis yaitu tanpa penghubung atau konjungsi.

Karena keanekaragaman bahasa terkadang konjungsi sulit dibedakan dengan preposisi atau terjadi tumpang tindih antara satu kelas kata dengan kelas kata lainnya. Dalam bahasa Indonesia kekaburan yang sering terjadi yaitu antara kelas kata konjungsi dengan kelas kata preposisi. Berikut ini contohnya:

\section{(1) Ia pergi karena saya \\ (2) Ia pergi karena saya mengusirnya.}

Berdasarkan kalimat (1) di atas konstituen karena merupakan preposisi karena diikuti oleh satuan kata ${ }^{8}$. Preposisi adalah adposisi yang dalam bahasa bertipe VO terletak di depan nomina. Pada kalimat (2) konstituen karena bukanlah preposisi melainkan merupakan sebuah konjungsi. Konstituen karena pada kalimat (2) dikategorikan sebagai konjungsi karena berfungsi menghubungkan satuan lingual yaitu klausa. Konstituen karena pada kalimat (2) menggabungkan klausa bebas Ia pergi dengan klausa terikat Karena saya mengusirnya. Walaupun bentuk dan posisi dari kedua konstituen tersebut sama, namun kategori karena pada kalimat (1) dengan karena yang terdapat pada kalimat (2) berbeda. Yang satu merupakan konjungsi sedangkan yang lainya adalah preposisi.

Hal yang serupa dengan permasalahan di atas juga terdapat dalam BJ. Adakalanya satu kategori dengan kategorinya tumpang tindih di dalam BJ. Seperti yang terjadi antara kategori case marking dengan kategori konjungsi. Dilihat dari bentuknya konstituen $g a$ memiliki dua kemungkinan. Pertama, dalam sebuah konstruksi konstituen $g a$ dapat menjadi sebuah konjungsi koordinatif seperti yang terdapat pada data

\footnotetext{
${ }^{7}$ Harimurti Kridalaksana, "Kelas Kata Dalam Bahasa Indonesia" (Jakarta: Gramedia Pustaka, 2008).

${ }^{8}$ Harimurti Kridalaksana.
} 
(6) di bawah. Kedua, pada konstruksi yang berbeda konstituen $g a$ berkemungkinan menjadi case marking atau penanda kasus seperti pada kalimat (3) di bawah ini. Van Valin dan Lapolla (1987) menyebutkan bahwa konstituen $g a$ adalah penanda fokus dalam BJ. Berikut ini contohnya:

\section{(3) Kuruma ga koshou shita. Mobil FOC rusak LAMP 'Mobil rusak'}

Pada kalimat (3) di atas konstituen $g a$ bukan konjungsi melainkan case marking fokus. Selain fungsinya yang bebeda dengan konstituen $g a$ yang ditemukan pada data (6), dari segi makna yang dimiliki pun terdapat perbedaan antara konstituen $g a$ yang terdapat pada data (6) dengan konstituen $g a$ yang terdapat pada kalimat (3). Pada data (6) konstituen ga memiliki makna gramatikal 'tetapi'. Sedangkan pada kalimat (3) konstituen ga tidak memiliki makna gramatikal. Pada kalimat (3) konstituen ga hanya memiliki fungsi yaitu sebagai penanda fokus. Terkait dengan persoalan fokus di dalam kalimat, hal ini berkaitan dengan relasi pragmatik atau struktur informasi sebuah kalimat. Di dalam BJ terdapat dua penanda kasus yang sering kabur batasan penggunaanya. Penanda kasus yang dimaksudkan tersebut yaitu penanda kasus topik dengan penanda kasus fokus. Penanda kasus topik di dalam BJ yaitu konstituen wa. Sementara itu, yang menjadi penanda kasus fokus yaitu konstituen ga. Topik merupakan atau merujuk kepada referen yang baru atau sesuatu yang menjadi perhatian di dalam konstruksi. Sedangkan referen yang sudah diidentifikasi ditandai dengan penanda fokus yaitu ga. Adapun pada kalimat (5) di atas fokus dapat dipicu oleh pertanyaan nani ga koshoushita 'apa yang rusak?'. Sehingga terlihat bahwa kuruma 'mobil' pada kalimat (3) di atas adalah fokus dan bukanlah topik.

Muslich $^{9}$ menyatakan konjungsi atau kata sambung adalah kata tugas yang menghubungkan dua klausa atau lebih. Menurutnya yang dihubungkan oleh konjungsi adalah klausa. Meskipun lebih jauh dia menambahkan bahwa konjungsi koordinatif yang jumlahnya lebih sedikit dibandingkan dengan konjungsi subordinatif juga dapat menghubungkan kata selain dari menghubungkan klausa.

Secara tradisional konjungsi terbagi atas dua jenis dilihat dari hubungan antar unit. Pertama, konjungsi koordinatif atau coordinating conjunction. Kedua, konjungsi subordinatif atau subordinating conjunction. Konjungsi koordinatif menghubungkan unit gramatikal yang masing-masing unit memiliki hubungan yang setara. Secara umum konjungsi koordinatif seperti dan, tetapi, atau atau equal 'menyamai' pada bahasa lainya ditemukan pada setiap bahasa. Maksud kata equal disini yaitu bahasa-bahasa di dunia cendrung memiliki konjungsi koordinatif yang bermakna sama dengan dan, tetapi, atau dalam BI. Konjungsi dan menandai suatu hubungan penambahan sehingga konjungsi ini dikenal bersifat aditif. Konjungsi atau menandai suatu hubungan yang bersifat pilihan atau alternatif. Konjungsi tapi menandai suatu hubungan pertentangan atau juga dapat dikatakan bersifat kontradiktif. Hampir setiap bahasa di dunia memiliki konjungsi koordinatif yang menandai suatu hubungan yang bersifat aditif, kontradiktif, dan alternatif.

Konjungsi koordinatif dan konjungsi subordinatif ditemukan pada setiap Bahasa, tak terkecuali dalam Bahasa Jepang. Di dalam bahasa Jepang juga ditemukan konjungsi koordinatif dan konjungsi subordinatif. Karena luasnya cakupan konjungsi, maka peneliti hanya

\footnotetext{
${ }^{9}$ Masnur Muslich, Garis-Garis Besar Tata Bahasa Baku Bahasa Indonesia (Bandung: PT. Refika Aditama, 2010).
} 
membatasi penelitian pada konjungsi koordinatif bahasa Jepang saja.

Konjungsi adalah kata tugas yang memiliki peranan penting dalam membangun struktur kalimat. Penggunaan konjungsi secara benar baik dalam bahasa tulis ataupun Bahasa lisan meruapakan sebuah kemampuan yang diperlukan bagi setiap pengguna bahasa ${ }^{10}$. Fungsi sebagai penghubung unit gramatikal atau penghubung sintaksis membuat frekuensi kemunculanya cukup tinggi di dalam sebuah konstruksi. Kesalahan atau ketidaktepatan penggunaan konjungsi menjadikan suatu konstruksi tidak berterima secara gramatikal. Selain itu, kesalahan dalam penempatan konjungsi di dalam kalimat dapat menimbulkan kesalahan maksud atau makna yang dikandung oleh kalimat tersebut. Penggunaan konjungsi dengan benar sangat menentukan keberterimaan suatu konstruksi secara gramatikal. Ketepatan penggunaan suatu konjungsi menentukan kelancaran dalam menyampaikan informasi dalam berkomunkasi. Apabila penggunaan konjungsi tidak sesuai dengan aturanya maka suatu konstruksi tidak akan berterima secara gramatikal dan juga tidak membawa makna yang sesuai dengan yang diharapkan, seperti pada kalimat (4) di bawah ini:

(4) *が 走っています

$\begin{array}{ll}\text { ga } & \text { hashitteimasu } \\ \text { KONJ berlari }\end{array}$

ちょっとも やせ ません chotto mo yase masen sedikit Par kurus Neg

'tetapi saya berlari, sedikitpun saya tidak bisa menurunkan berat badan'

Kalimat (4) di atas merupakan salah satu contoh ketidaktepatan penggunaan

\footnotetext{
${ }^{10}$ Oktavian Aditya Nugraha, Abdul Ngalim, and Yakub Nasucha, "Penggunaan Konjungsi Dalam Bahasa Tulis Dan Lisan Oleh Siswa Kelas Lima
}

konjungsi BJ di dalam kalimat. Kesalahan terjadi pada penempatan konjungsi atau letak struktural konjungsi. Konjungsi koordinatif aditif $g a$ pada kalimat (4) di atas akan berfungsi sebagaimana mestinnya jika ditempatkan di antara unsur yang digabungkan dan bukan ditempatakan di awal.

Berdasarkan latar belakang di atas peneliti tertarik untuk meneliti konjungsi koordinatif BJ. Penelitian ini dilakukan pada konjungsi koordinatif BJ yang terdapat dalam biografi Hellen Keller yang ditulis oleh Sukeyuki Imanishi, esai Read Real Japanese, dan kumpulan cerpen Dondon Yomeru hanashi. Ketertarikan penulis terhadap tokoh kemanusiaan dunia yaitu Helen Keller menjadi salah satu alasan menjadikan biografi ini sebagai sumber data. Helen Keller mulai belajar bahasa pada usia yang tidak sama dengan anak-anak pada umumnya. Helen adalah seorang anak yang buta dan tuli, gurunya mengajari Helen berbahasa dengan membaca huruf Braille. Helen belajar menemukan makna sebuah kata melalui bacaan. BJ yang digunakan di dalam biografi ini tidak menggunakan pola kalimat yang sulit serta mudah untuk dibaca dan dipahami baik makna maupun struktur kalimatnya.

Esai Read Real Japanese merupakan kumpulan dari beberapa esai yang dijadikan buku dan diterbitkan oleh Kondansha pada tahun 2008. Esai ini ditulis oleh pengarang Jepang yang sudah mengeluarkan karya terkenal baik di Jepang maupun luar negri seperti Murakami Haruki dan Banana Yoshimoto. Kumpulan esai ini berisikan tulisan kontemporer. Kata "kontemporer" berkaitan dengan modernisasi dan masa kini. Kumpulan esai ini merupakan karya yang merefleksikan masa kini baik dari segi bahasa maupun tema yang diangkat. Biografi Helen Keller, Esai Read Real

Bakti Pandeyan 01 Sukoharjo," Jurnal Penelitian Humaniora 16, no. 2 (Agustus 2015): 43-50. 
Japanese, dan kumpulan cerpen Don Don Yomeru Iroiro Na Hanashi merupakan bacaan yang popular di Jepang. Ketiga sumber bacaan ini menggunakan bahasa yang cukup sederhana baik dari tata bahasa maupun penggunaan huruf kanji terutama dalam cerpen Don Don Yomeru Iroiro Na Hanashi.

Yang menjadi rumusan masalah dalam penelitian ini yaitu (1) Bagaimanakah bentuk konjungsi koordinatif bahasa Jepang dalam Biografi Helen Keller, Esai Read Real Japanese, dan Kumpulan cerpen Dondon Yomeru Hanashi? (2) Bagaimanakah perilaku gramatikal konjungsi koordinatif bahasa Jepang dalam biografi Helen Keller, Esai Read Real Japanese, dan Kumpulan cerpen Dondon Yomeru Hanashi.

Penelitian ini bertujuan untuk menjelaskan mengenai bentuk konjungsi koordinatif bahasa Jepang dan menjelaskan serta mendeskripsikan perilaku gramatikal konjungsi koordinatif bahasa Jepang. Perilaku gramatikal konjungsi koordinatif bahasa Jepang meliputi tugas atau fungsi konjungsi, letak struktural konjungsi koordinatif, dan sifat kehadiran konjungsi koordinatif di dalam konstruksi gramatikal.

Hasil penelitian ini diharapkan memberikan manfaat terhadap (1) pengembangan teori linguistik mengenai konjungsi koordinatif bahasa Jepang; (2) menjadi acuan atau bahan rujukan untuk penelitian berikutnya.

Penelitian mengenai konjungsi bahasa atau konjungsi bahasa Jepang khususnya sudah ada yang melakukannya. Namun berbeda dengan penelitian-penelitian terdahulu, penelitian ini menggunakan tinjauan sintaksis serta rumuasan masalah yang berbeda. Penelitian penelitian terdahulu mengenai konjungsi tersebut seperti penelitian yang telah dilakukan oleh Al-Buqori yang berjudul

${ }^{11}$ Al-Buqori, "Setsuzokushi Aruiwa Dan Soretomo Dalam Bahasa Jepang” (Andalas University, 2014). setsuzokushi aruiwa dan soretomo dalam bahasa Jepang ${ }^{11}$. Peneliti mengambil data tertulis dari novel. Jumlah konjungsi yang diteliti yaitu ada dua, konjungsi aruiwa dan konjungsi soretomo. Kedua konjungsi ini dalam BJ memiliki makna yang hampir sama. Peneliti melakukan penelitian untuk melihat perbedaanya dari sudut pandang sintaksis. Dari hasil penelitian ditemukan bahwa konjungsi aruiwa dilihat dari posisinya di dalam konstruksi dapat terletak di awal dan di tengah kalimat. Dan lagi, unit yang dapat dihubungkan oleh konjungsi aruiwa yaitu frasa dengan frasa serta kalimat dengan kalimat. Konjungsi soretomo juga dapat menghubungkan frasa, klausa, dan kalimat, dan juga posisinya dapat terletak di awal dan di tengah unit lingual yang dihubungkan.

Berdasarkan penelitian yang telah dilakukan oleh Albuqori ditemukan perbedaan antara konjungsi aruiwa dan konjungsi soretomo meskipun secara posisi struktural dan jenis unit lingual yang dapat di hubungkan oleh kedua konjungsi ini tidak ada perbedanya. Perbedaan yang ditemukan antara konjungsi aruiwa dengan konjungsi soretomo tersebut yaitu konjungsi aruiwa dapat digunakan pada kalimat afirmatif dan introgatif sedangkan konjungsi soretomo hanya digunakan pada kalimat introgatif saja.

Penelitian berikutnya yaitu oleh Ratnawati $^{12}$ yang berjudul Konjungsi dan Klausa Subordinatif dalam Bahasa Jawa. Penelitian ini menggunakan dua tinjauan yaitu tinjauan semantik dan sintaksis. Dalam penelitianya, Ratnawati menyebutkan bahwa terjadi overlap penggunaan konjungsi koordinatif dan subordinatif di dalam bahasa Jawa. Tidak seperti bahasa lainya, di dalam bahasa Jawa tidak jelas garis pemisah antara konjungsi koordinatif dengan konjungsi

12 Ratnawati, "No TitleKonjungsi Dan Klausa Subordinat Dalam Bahasa Jawa" (Universitas Indonesia, 1994). 
subordinatif. Namun sayangnya, dalam penelitian Ratnawati ini tidak ditemukan analisis dan deskripsi yang lebih rinci mengenai perbedaan antara kojungsi koordinatif dengan konjungsi subordinatif di dalam bahasa Jawa. Penelitian yang dilakukan oleh Ratnawari ini lebih cendrung kepada tinjauan sintaksis dan semantis dari konjungsi dan klausa subordinatif dalam bahasa Jawa saja.

Selanjutnya penelitian yang dilakukan oleh Ismail $^{13}$ yang berjudul Konjungsi Youni dan Tameni dalam Bahasa Jepang. Latar belakang dari penelitian ini yaitu karena kemiripan makna dari konjungsi youni dengan konjungsi tameni. Karena kemiripan makna antara konjungsi youni dengan konjungsi tameni peneliti tertarik untuk melihat perbedaan dan persaman kedua konjungsi ini secara lebih dalam. Tinjauan yang digunakana yaitu tinjauan semantik. Dari penelitian yang dilakukan oleh Ismail ini ditemukan bahwa konjungsi tameni dan konjungsi youni digunakan pada kalimat yang mengandung makna kepentingan, keinginan, perintah, permintaan, dan manfaat. Perbedaan dari kedua konjungsi ini yaitu konjungsi tameni tidak dapat digunakan pada kalimat yang mengandung makna perintah. Sedangkan konjungsi youni tidak dapat digunakan pada kalimat tujuan yang mengandung makna kepentingan.

\section{B. Metode}

Penelitian ini merupakan penelitian deskriptif menggunakan pendekatan kualitatif. Dikatakan sebagai penelitian deskriptif karena sifatnnya yang berupa pemamaparan, memaparkan secara

\footnotetext{
${ }^{13}$ Ismail, "Konjungsi Tameni Dan Youni Dalam Bahasa Jepang (Kajian Semantik)" (Andalas University, 2009).

14 T. Fatimah Djajasudarma, Metode Linguistik: Ancangan Metode Penelitian Dan Kajian (Bandung: PT. Refika Aditama, 2006).

${ }^{15}$ Eugene A Nida, Morphology: The Descriptive Analysis of Word. (Ann Arbor: The University of Michigan Press, 1963).
}

deskripsi terhadap objek penelitian yang di teliti. Djajasudarma ${ }^{14}$ menyatakan bahwa sebuah penelitian deskriptif memberikan gambaran dan ciri-ciri data secara akurat sesuai dengan sifat alamiah data itu sendiri. Dengan kata lain, penelitian deskriptif dilakukan berdasarkan fakta yang ada dengan memberikan gambaran secara objektif tentang keadaan yang sebenarnya yang sedang diteliti. Menurut Nida ${ }^{15}$ penelitian deskriptif memiliki berberapa karakteristik yaitu (1) analisis yang dilakukan harus berdasarkan pada apa yang diujarkan, (2) bentuk merupakan hal utama, sedangkan makna adalah bagian kedua, (3) tidak ada bahasa yang dapat dijelaskan prinsipnya tanpa mengacu pada bagian lain, (4) bahasa selalu berubah. Adapun pendekatan yang digunakan dalam penelitian ini yaitu pendekatan kualitatif. Afifuddin ${ }^{16}$ mengatakan pendekatan kualitatif menekankan pada makna penalaran, definisi suatu situasi tertentu (dalam konteks tertentu) dan mementingkan proses dibandingkan hasil akhir.

Dalam sebuah penelitian khususnya penelitian bahasa yang dijadikan sebagai bahan jadi penelitian adalah data. Menurut Sudaryanto dalam Kesuma ${ }^{17}$ data adalah objek penelitian ditambah dengan konteks.

Dalam penelitian ini, sumber data berasal dari sumber tertulis. Sumber data yang berasal dari data tertulis diperoleh dari biografi berjudul Heren Kera Jiten atau biografi Helen Keller oleh Imanishi Sukeyuki, Esai Read Real Japanese, dan kumpulan cerpen Don Don Yomeru Hanashi. Adapun yang menjadi populasi

\footnotetext{
${ }^{16}$ Beni Ahmad Saebani Afifuddin, Metodologi Penelitian Kualitatif (Bandung: CV. Pustaka Setia, 2009).

17 Tri Mastoyo Jati Kesuma, "Pengantar (Metode) Penelitian Bahasa” (Yogyakarta: Crasvatibooks, 2007).
} 
dalam penelitian ini yaitu keseluruhan kalimat yang mengandung konjungsi koordiantif dalam bahasa Jepang. Sementara itu yang menjadi sampel adalah konjungsi koordinatif yang mewakili jenis keseluruhan populasi yang telah dipilah dari sumber data yaitu biografi Heren Kera Jiten, Esai Read Real Japanese, dan kumpulan cerpen Don Don Yomeru Hanashi. Peneliti menggunakan ketiga teks ini sebagai sumber data penelitian karena tersediannya data penelitian yang dibutuhkan dan Bahasa Jepang yang digunakan di dalam ketiga teks ini tergolong mudah untuk dipahami oleh peneliti.

Metode yang digunakan dalam penjaringan data yaitu metode simak. Teknik dasar yang digunakan adalah teknik sadap. Sementara itu teknik simak bebas libat cakap menjadi teknik lanjutan dalam penjaringan data dalam tulisan ini. Teknik sadap yaitu teknik yang dilakukan dengan menyadap penggunaan bahasa seseorang. Penyadapan ini dapat berupa bahasa lisan dan bahasa tulisan. Namun oleh karena sumber data adalah berupa tulisan. Untuk itu teknik yang paling tepat digunakan adalah teknik simak bebas libat cakap karena peneliti tidak terlibat di dalamnnya.

Dalam hal ini, pertama peneliti membaca seluruh kalimat yang ada di dalam biografi Helen Keller, Esai Read Real Japanese, dan kumpulan cerpen Don Don Yomeru Hanashi. Selanjutnya, peneliti menyadap setiap kalimat yang terdapat konjungsi koordinatif di dalamnnya. Kemudian, peneliti mencatat data ke dalam kartu data.

Metode analisis data adalah cara-cara khas tertentu yang ditempuh peneliti untuk memahami problematika satuan kebahasaan yang diangkat sebagai objek penelitian ${ }^{18}$. Adapun metode yang peneliti gunakan dalam menganalisis data di

${ }^{18}$ Sudaryanto, Metode Dan Teknik Analisis Bahasa: Pengantar Penelitian Wahana dalam penelitian ini yaitu metode padan dan metode agih atau disebut juga dengan metode distribusional beserta tekniktekniknnya.

Metode padan yang peneliti gunakan yaitu metode padan translasional. Metode padan translasional digunakan dalam pemindahan arti dari bahasa Jepang ke bahasa Indonesia. Sementara itu, teknik dasar yang digunakan adalah teknik pilah unsur penentu, yaitu teknik analisis data dengan cara memilah-milah satuan kebahasaan yang dianalisis dengan alat penentu berupa daya pilah yang bersifat mental yang dimiliki oleh setiap peneliti.

Selain metode padan peneliti juga menggunakan metode agih. Metode agih yaitu metode yang alat penentunnya ada di dalam bahasa itu sendiri. Adapun teknik dasar yang digunakan yaitu teknik bagi unsur langsung. Teknik bagi unsur langsung digunakan untuk memilah dan mengetahui jenis unit lingual yang dihubungkan oleh konjungsi.

Metode yang digunakan untuk menyajikan hasil analisis data yaitu metode formal dan nonformal. Sudaryanto $^{19}$ menyatakan, penyajian hasil analisis data secara informal adalah penyajian hasil analisis data dengan menggunakan kata-kata biasa. Sementara itu, penyajian hasil analis data secara formal adalah penyajian hasil analisis data dengan menggunakan kaidah. Kaidah itu dapat berupa rumus, bagan/diagram, tabel dan gambar. Pada penelitian ini peneliti akan menggunakan tabel sebagai metode formal dalam penyajian hasil analisis data. Sedangkan dalam penyajian nonformal peneliti akan menggunakan kata-kata.

\section{Temuan dan Pembahasan}

Konjungsi koordinatif berjumlah lebih sedikit dibandingkan dengan konjungsi subordinatif. Konjungsi jenis ini dapat menandai hubungan penambahan atau

Kebudayaan Secara Linguistis (Yogyakarta:

Sanata Dharma University Press, 2015).

${ }^{19}$ Sudaryanto. 
aditif, pemilihan atau alternatif dan hubungan mempertentangkan atau kontradiktif. Konjungsi aditif menambahkan antara unit yang satu dengan unit yang lain, konjungsi alternatif untuk memilih antara unit yang satu dengan yang lainya, sementara itu konjungsi kontradiktif berfungsi untuk mempertentangkan antara unit yang satu dengan unit yang lainnya.

\section{Konjungsi Koordinatif Menandai "Penambahan/Aditif"}

Konjungsi koordinatif Aditif mengikat unit lingual yang kedudukanya sama atau setara di dalam konstruksi sintaksis ${ }^{20}$. Hubungan yang setara itu dapat dilihat dari kelas kata atau jenis kata yang digabungkan atau dihubungkan oleh konjungsi. Dalam bahasa Jepang ditemukan beberapa bentuk konjungsi koordinatif yang menandai hubungan penambahan atau bersifat aditif. Konjungsi-konjungsi tersebut yaitu konjungsi koordinatif to, konjungsi koordinatif ya dan konjungsi koordinatif shi seperti yang diuraikan pada bagian di bawah ini.

\section{Konjungsi Koordinatif to 'Dan'}

Konjungsi koordinatif to dalam BJ berasal dari kelas kata partikel. Partikel merupakan bentuk yang terbatas kebebasannya tetapi berstatus kata. Jika dibandingkan dengan leksikon bebas, partikel masih memiliki keterbatasan. Leksikon bebas umumnya memiliki makna leksikal sedangkan partikel hanya memilikiki makna gramatikal.

Konstituen to meruapkan konjungsi koordinatif yang menghubungkan unit lingual berupa kata. Konjungsi to selain berfungsi menghubungkan kata dengan kata juga berfungsi sebagai noun lister atau mengurutkan beberapa benda yang sifatnnya exhaustive atau keseluruhan.
Seperti yang ditunjukan oleh data di bawah ini:

$\begin{array}{ccc}\text { (1) パンチ } & \text { と } & \text { はさみ を } \\ \text { panci } & \text { to hasami wo } \\ \text { pelubang } & \text { kertas } & \text { KONJ gunting } \mathrm{AKU}\end{array}$

$\begin{array}{lll}\text { 入れたりする } & \text { の } & \text { を.... } \\ \text { Iretarisuru } & \text { no } & \text { wo } \\ \text { memasukan } & \text { GEN } & \text { AKU } \\ \text { ‘(Konduktor) memasukan gunting dan } \\ \text { pelubang kertas' }\end{array}$

Berdasarkan data (1) di atas konstituen to mengikat unit gramatikal atau satuan lingual berupa kata dalam sebuah konstruksi sintaksis. Pada data (1) to mengikat nomina dengan nomina. Nomina yang diikat oleh to yaitu panci 'pelubang kertas' dan hasami 'gunting'. Berdasarkan analisis data di atas yaitu data (1) dapat disimpulkan bahawa konjungsi to mengikat unit gramatikal atau satuan lingual berupa kata. Konjungsi koordinatif to tidak dapat mengikat unit lingual berupa klausa.

Dikarenakan konstituen to dapat mengikat unsur yang sifatnya setara di dalam sebuah konstruksi sintaksis maka konstituen to dikategorikan sebagai konjungsi koordinatif. Untuk membuktikan bahwa konstituen to merupakan konjungsi koordinatif maka dilakukan pengujian dengan melihat kedudukan unit yang diikat atau dihubungkan oleh konjungsi tersebut. Sebuah konstituen dikategorikan sebagai konjungsi koordinatif apabila konstituen tersebut mampu mengikat atau menghubungkan unit garamatikal yang kedudukanya setara atau sama

Berdasarkan data (1) konstituen to menghubungkan nomina dengan nomina. Tidak ditemukan konstituen to yang mengikat atau menghubungkan satuan lingual yang kelas katanya berbeda seperti nomina dengan verba ataupun verba dengan adverbia. Oleh karena itu dapat

\footnotetext{
${ }^{20}$ Cici Puspita Sari, "Konjungsi Koordinatif Aditif Bahasa Sunda," EJurnal Mahasiswa Universitas Padjajaran 1, no. 1 (2012).
} 
disimpulkan bahwa konstituen to adalah konjungsi koordinatif yang menghubungkan satuan lingual yang kedudukanya setara.

Letak konjungsi koordinatif to juga dapat digambarkan dengan A co B, yang mana $\mathbf{A}$ merupakan nomina pertama atau N1 dan B merupakan nomina kedua atau N2. Letak konjungsi koordinatif to adalah tegar. Posisi konjungsi koordinatif to tidak dapat dirubah atau dimutasikan menjadi *co AB ataupun ${ }^{*} \mathbf{A B}$ co. Seperti kalimat di bawah ini:

(1a) *...とパンチ
to panci
KONJ pelubang

$\begin{array}{lll}\text { 入れたりする } & \text { の } & \text { を.... } \\ \text { Iretarisuru } & \text { no } & \text { wo } \\ \text { memasukan } & \text { GEN } & \text { AKU } \\ \text { '(Konduktor) memasukan gunting } \\ \text { pelubang kertas' }\end{array}$

Kalimat (1a) di atas tidak berterima karena konjungsi to tidak memiliki fungsi apapun di dalam konstruksi tersebut. Pada kalimat (1a) konjungsi to terletak mengawali nomina pertama. letak struktural ini membuat konjungsi to kehilangan fungsinya sebagai konjungtor. Konjungsi koordinatif to hannya berfungsi sebagai konjungtor jika berada di antara nomina yang digabungkan seperti pada data (1). Karena tidak dapat mengawali atau berada di akhir unit lingual yang digabungkan maka letak struktural konjungsi koordinatif to adalah tegar. Konjungsi to selain berfungsi atau bertugas sebagai penghubung satuansatuan lingual juga berfungsi sebagai noun lister yaitu dapat digunakan untuk menjajarkan atau mengurutkan beberapa nomina di dalam sebuah kalimat. Jumlah nomina yang dapat di jajarkan tidak terbatas. Pada data (1) konjungsi koordinatif to menggabungkan dua buah nomina yaitu panci 'pelubang kertas' dengan hasami 'gunting'.
Kehadiran konjungsi koordinatif to di dalam konstruksi tidak dapat dilesapkan. Apabila konjungsi koordinatif to di lesapkan maka konstruksi tidak berterima secara gramatikal. Oleh karena itu dikatakan bahwa sifat kehadiran konjungsi koordinatif to adalah wajib.

$$
\begin{array}{ccc}
\text { (1b) *... パンチ } & \multicolumn{2}{c}{\text { はさみ }} \\
\text { panci } & \text { hasami wo } \\
\text { pelubang } & \text { kertas } & \text { gunting AKU } \\
& & \\
\text { 入れたりする } & の & \text { を... } \\
\text { Iretarisuru } & \text { no } & \text { wo } \\
\text { memasukan } & \text { GEN } & \text { AKU } \\
\text { '(Konduktor) memasukan gunting } \\
\text { pelubang kertas' }
\end{array}
$$

Kalimat (1b) di atas tidak berterima karena tidak ditemukan adanya konjungtor yang bertugas menggabungkan nomina panic dengan nomina hasami. Konjungtor tersebut seharusnnya berfungsi menggabungakan nomina-nomina tersebut. Namun, karena dilesapkan maka konstruksi menjadi tidak berterima secara gramatikal. Untuk itu dapat dikatakan bahwa kadar keintian suatu unsur yaitu konjungsi koordinatif to di dalam kalimat bersifat wajib. Konjungsi to tidak dapat dihilangkan di dalam konstruksi (1b) di atas.

\section{Konjungsi Koordinatif ya 'Dan'}

Selain dari konstituen to, ditemukan konstituen lainya yang juga dapat digunakan untuk menghubungkan unit lingual di dalam sebuah konstruksi yaitu konjungsi koordinatif ya. Konjungsi koordinatif ya mampu mengikat atau menghubungkan satuan lingual berupa kata. Seperti pada data (2) di bawah ini:

\section{(2) ...ガウス や 藤原先生 $\begin{array}{lcc}\text { Gauss } & \text { ya } & \text { Fujiwarasensei } \\ \text { Gauss } & \text { KONJ } & \text { Fujiwara }\end{array}$}

$\begin{array}{ccc}\text { の ような } & \text { 人たち が..... } \\ \text { no youna hitotachi }\end{array}$
$g a$ 


\section{FOC}

GEN seperti orang-orang

'Untuk orang seperti Gaus dan

Fujiwara'

Pada data (2) di atas konjungsi koordinatif ya berfungsi menggabungkan kata gausu 'Gaus' dengan kata fujiwarasense 'guru Fujiwara'. Kedua kata yang digabungkan oleh konjungsi ya tersebut berkategori nomina.

Konjungsi ya termasuk ke dalam konjungsi koordinatif. Konjungsi koordinatif adalah konjungsi yang mengikat atau menghubungkan unit yang sifatnya setara. Kesetaraan tersebut dapat dilihat dari kelas kata serta jenis unit yang dihubungkan.

Konjungsi ya menghubungkan nomina dengan nomina. Berdasarkan analisis data tidak ditemukan adanya konjungsi ya yang menghubungkan nomina dengan verba, verba dengan adverbia, dan adverbia dengan nomina.

Letak struktural konjungsi koordinatif ya di dalam kalimat yaitu berada di antara satuan lingual yang dihubungkan. Posisi struktural konjungsi koordinatif ya dapat digambarkan dengan A co B. A merupakan nomina pertama atau NI dan B adalah nomina kedua atau N2. Letak struktural konjungsi ya di dalam kalimat adalah tegar dan tidak dapat dimutasikan dengan posisi lainya seperti $* \mathbf{A B c o}$ atau *coAB. Jika dilakukan mutasi atau pemindahan posisi konjungsi koordinatif ya di dalam kalimat, maka kalimat tidak berterima secara gramatikal, seperti yang ditunjukan oleh kalimat (2a) di bawah ini.

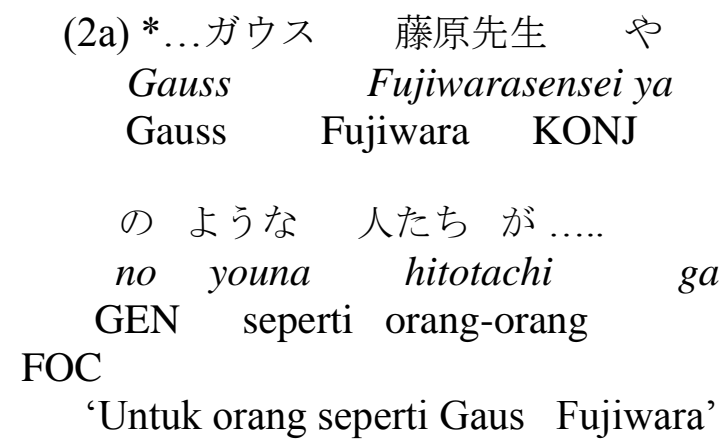

Kalimat (2a) di atas tidak berterima karena posisi konjungsi koordinatif ya dimutasikan yang seharusnnya berada di antara satua lingual yang digabungkan menjadi berada di akhir nomin ke dua atau N2. Hal ini membuat konjungsi koordinatif ya pada kalimat (2a) kehilangan fungsinnya sebagai konjungtor atau penghubung satuan lingual.

Selain dari letak strukturalnya yang tegar sifat kehadiran konjungsi koordinatif ya di dalam konstruksi adalah wajib. Apabila konjungsi koordinatif ya di lesapkan pada maka konstruksi tidak berterima secara gramatikal. Seperti yang terjadi pada kalimat (2b) di bawah.

$$
\begin{aligned}
& \text { (2b) *...ガウス 藤原先生 } \\
& \text { Gauss Fujiwarasensei } \\
& \text { Gauss Fujiwara } \\
& \text { のような 人たち が ..... } \\
& \text { no youna hitotachi ga } \\
& \text { FOC } \\
& \text { GEN seperti orang-orang }
\end{aligned}
$$

Kalimat (2b) di atas tidak berterima karena konjungsi koordinatif ya dilesapkan sehingga konstruksi kehilangan bagian yang berperan sebagai konjungtor nomina gausu dengan nomina fujiwarasense.

Konjungsi ya memiliki persamaan baik dari segi ciri struktural maupun maknanya dengan konjungsi to. Pertama, konjungsi ya dan konjungsi to adalah konjungsi koordinatif. Kedua, konjungsi ya dan konjungsi to memiliki fungsi untuk mengikat dan menghubungkan unit gramatikal berupa kata. Ketiga, konjungsi ya dan konjungsi to mampu menghubungkan kata dengan kategori nomina. Keempat, kedua konjungsi ini sama-sama menandai hubungan penambahan atau aditif. Kelima, apabila diterjemahkan ke dalam bahasa Indonesia konjungsi ya beserta konjungsi to sama- 
sama dipadankan dengan kata 'dan'. Keenam, letak konjungsi koordinatif ya dan konjungsi koordinatif to yaitu berada di antara satuan lingual yang dihubungkan. Ketujuh, Sifat kehadiran konjungsi koordinatif ya dan konjungsi koordinatif to di dalam konstruksi adalah wajib.

Selain memiliki peersamaan dengan konjungsi to konjungsi ya juga memiliki perbedaan dengan konjungsi to. Pertama, konjungsi to bersifat exhaustive atau menghubungkan item secara keseluruhan. Maksudnnya di sini yaitu apabila konjungsi to digunakan untuk menghubungkan atau menajajarkan beberapa nomina di dalam suatu konstruksi maka nomina yang dijajarkan atau dihubungkan tersebut sudah keseluruhanya. Berbeda dengan konjungsi to, konjungsi koordinatif ya hanya mewakili beberapa nomina saja sehingga dikatakan bersifat representative atau inexhaustive. Perbedaan lainya yaitu dalam penggunanya konjungsi ya diikuti oleh partikel nado 'dan lain-lainya' sedangkan konjungsi to tidak diikuti oleh partikel nado. Seperti yang terdapat pada data (3) di bawah ini konjungsi koordinatif ya diikuti oleh partikel nado.

\begin{tabular}{clll} 
(3) その & 辺 & は & \multicolumn{1}{c}{ アメリカ人 } \\
sono & hen & wa & Amerika jin \\
sana & sekitar & TOP & Amerika orang \\
人 & イギリス人 & や & フランス \\
ya & Iigirisujin & ya & furansu \\
jin & & & \\
KONJ & Inggris orang & KONJ Perancis \\
orang & & & \\
など & が たくさん & 住んでい まし \\
た & & \\
nado ga takusan sundei mashita \\
lainnya FOC bannyak tinggal LAMP \\
'Di sekitar sana banyak tinggal \\
orang Amerika, Inggris, Perancis dan \\
lainnya'
\end{tabular}

Seperti yang terdapat pada data (3) konjungsi koordinatif ya diikuti oleh partikel nado. Konstituen nado mengindikasikan bahwasanya masih ada nomina lainya yang tidak disebutkan atau dimunculkan di dalam konstruksi selain dari nomina Igirisujin, Amerikajin, dan Furansujin di dalam data (3). Dalam penggunanya bersama konjungsi koordinatif ya partikel nado tidak selalu hadir mengikuti konjungsi ya di dalam sebuah konstruksi sintaksis.

\section{Konjungsi Koordinatif shi 'dan'}

Konjungsi koordinatif shi tidak berbeda dalam hal makna gramatikal dengan konjungsi koordinatif sebelumnnya yaitu jika dipadankan ke dalam bahasa Indonesia konjungsi ini dipadankan dengan kata 'dan'. Konjungsi koordinatif shi juga menandakan hubungan aditif atau penambahan. Akan tetapi, berdasarkan bentuknya konjungsi sebelumnnya yaitu konjungsi koordinatif to dan ya berasal dari kelas kata partikel, sedangkan konjungsi koordinatif shi merupakan afiks yang selalu melekat pada unsur predikat.

Konstituen shi merupakan konjungsi koordinatif yang juga menandai hubungan penambahan/aditif di dalam BJ. Namun berbeda dengan konjungsi to dan konjungsi $y a$, konjungsi shi mengikat unit gramatikal berupa klausa. Konjungsi koordinatif shi menggabungkan dua uah kalusa atau lebih yang kedudukannya sama atau setara. Dengan kata lain antara satu klausa dengan klausa lainnya yang digabungkan tidak ada posisinnya yang lebih tinggi ataupun yang lebih rendah seperti yang terjadi antara klausa subordinat dengan klausa matrik. Kedua klausa yang digabungkan oleh konjungsi koordinatif shi sama-sama dapat membentuk kalimat tunggal atau simple sentence. Penggunaan konjungsi shi di dalam kalimat selain sebagai penghubung satuan lingual juga berfungsi menunjukan penambahan informasi. 
$\begin{array}{lll}\text { (4) 暖かい 砂 } & \text { の } \text { 上 に } \\ \text { atatakai suna } & \text { no } \\ \text { ue ni }\end{array}$ hangat pasir GEN atas di

$\begin{array}{lllll}\text { 飛び出 } & \text { し } & \text { 海 } & \text { の } & \text { 中 } \\ \text { tobida } & \text { shi } & \text { umi } & \text { no } & \text { naka } \\ \text { terbang } & \text { KONJ laut } & \text { GEN dalam }\end{array}$

$$
\begin{array}{cl}
\text { 人 飛び込んでいき } & \text { ました。 } \\
e \text { tobikondeiki } & \text { mashita } \\
\text { ke } \quad \text { masuk } & \text { LAMP }
\end{array}
$$

'terbang di atas pasir yang hangat dan masuk ke dalam laut'

Berdasarkan data (4) di atas terlihat bahwa konjungsi koordinatif shi mengikat dua buah klausa dalam konstruksi kalimat majemuk setara. Data (4) di atas terdiri atas dua klausa yang masing-masing klausa berpotensi menjadi kalimat tunggal. Klausa pertama pada data (4) di atas yaitu atatakai suna no ue ni tobida shi 'terbang di atas pasir yang hangat' dan klausa kedua umi no naka e tobikondeiki mashita 'masuk ke dalam laut'.

Dilihat dari korelasi temporal atau hubungannya dengan waktu, bedasarkan ketiga data di atas konjungsi shi digunakan sebagai konektor klausa yang menunjukan hubungan berurutan. Seperti pada data (5) di bawah klausa pertama dalam konstruksi tersebut yaitu densya ni sesshoku shi 'jatuh di kereta' lalu diikuti oleh klausa ke dua yaitu ookega wo suru jiken ga arimashitakke 'ada luka-luka yang disebabkan oleh kecelakaan'. Secara kronologis, peristiwa pada klausa pertama terjadi lebih dahulu, baru peristiwa pada klausa kedua, dan tidak terjadi sebaliknnya.

(5) 電車に接触 し 大怪我 densya ni sesshoku shi ookega kereta di jatuh KONJ luka

をする 事件 がありましたっけ wo suru jiken ga arimashitakke AKU terjadi kecelakan FOC ada'
'(Seorang wanita) jatuh di kereta dan ada luka-luka yang disebabkan oleh kecelakaan'

Konjungsi koordinatif shi dapat ditemukan pada konstruksi kalimat majemuk setara atau compound sentence. Berdasarkan letak strukturalnya, konjungsi shi terletak di antara satuan yang digabungkan. Konjungsi shi tidak dapat mengawali satuan yang digabungkan. Namun demikian, pada kondisi tertentu konjungsi shi dapat mengawali satuan yang digabungkan yaitu ketika terjadi pengulangan konjungsi di dalam sebuah konstruksi.

Gambaran letak struktural konjungsi koordinatif shi di dalam kalimat majemuk setara adalah A co B. A merupakan klausa pertama, B klausa kedua, dan co adalah konjungsi koordinatif shi. Gambaran letak struktural di atas dapat ditemukan pada kalimat majemuk yang dibentuk dari dua buah satuan lingual berupa klausa. Akan tetapi, jika suatu konstruksi dibentuk lebih dari dua klausa dan konjungsi shi digunakan sebagai penghubungnnya, maka letak strukturalnnya menjadi A co B co C. A, B, C merupakan satuan yang digabungkan dan co merupakan konjungsi koordinatif shi.

\section{(4a)*し 暖かい砂の上に飛び出} shi atatakai suna no ue ni tobida KONJ hangat pasir GEN atas di terbang laut

海 の 中 飛び込んでいき ました umi no naka e tobikondeiki mashita GEN dalam ke masuk LAMP KONJ hangat pasir GEN atas di terbang laut

'dan terbang di atas pasir yang hangat masuk ke dalam laut.'

Kalimat (4a) di atas menjadi tidak berterima karena letak struktural konjungsi shi yang semula berada di antara unsur yang digabungkan dirubah menjadi berada di awal unsur yang 
digabungkan. Posisi ini tidak berterima karena mengacaukan susunan sintakksis kalimat (4a) dan menimbulkan makna yang tidak koheren.

Menurut bentuknya, konjungsi shi merupakan afiks. Konjungsi shi tidak dapat berdiri sendiri dan melebur ke dalam morfem lainnya. Konjungsi shi biasanya ditemukan setelah unsur predikat. Oleh karena unsur predikat klausa bahasa Jepang terletak di akhir, maka konstituen shi selalu ditemukan setelah unsure predikatif.

Dari kedua data di atas yaitu data (4) sampai dengan (5) unsur predikatif yang ditempati oleh konjungsi shi yaitu tobibida 'masuk' dan sesshoku 'jatuh'. Verba yang menempati fungsi predikat pada data (4) hingga data (5) memiliki bentuk dasar yaitu tobidasu 'masuk atau memasuki' dan seshhoku suru 'mendorong'. Ketika ditambahkan dengan konjungsi shi, verba kedua data di atas dirubah dari bentuk dasarnya agar dapat ditambahkan dengan konjungsi shi. Caranya dengan menghilangkan stem yang berbunyi $u$ yaitu -suru pada verba seshoku dan -su pada verba tobidasu lalu ditambahkan dengan konjungsi shi. Sehingga secara berurutan verba yang terdapat pada kedua data di atas yaitu data (4) hingga data (5) setelah ditambahkan dengan konjungsi shi menjadi seshoku-shi dan tobida-shi.

Dalam sebuah konstruksi terkadang ada unsur yang dapat dilesapkan tanpa mengganggu susunan sintaksis konstruksi. Apabila suatu unsur dapat dilesapkan maka unsur tersebut tidak wajib hadir di dalam sebuah konstruksi. Namun, jika ketidakhadiran sebuah unsur atau konstituen menyebabkan rusaknnya susunan sebuah konstruksi sintaksis dan tidak kohenrennya makna yang dihasilkan oleh konstruksi, maka kehadiran unsur tersebut adalah wajib sifatnya.

Berdasarkan data (4) dan data (5) di atas diketahui bahwa konjungsi koordiantif shi bertugas menggabungkan dua buah klausa bebas untuk membentuk konstruksi kalimat majemuk setara. Dilihat dari sifat kehadiran konjungsi koordinatif $s h i$ wajib hadir di antara satuan lingual yang digabungkan. Apabila konjungsi koordinatif shi dilesapkan maka kalimat tidak berterima secara gramatikal, seperti pada kalimat di bawah ini:

$$
\begin{aligned}
& \text { (5a)*電車に接触 大怪我 を } \\
& \text { densya ni sesshoku ookega } \\
& \text { wo } \\
& \text { kereta di jatuh luka } \\
& \text { AKU } \\
& \text { する 事件 が ありましたっけ } \\
& \text { suru jiken ga } \\
& \text { arimashitakke } \\
& \text { terjadi kecelakan FOC ada' } \\
& \text { '(Seorang wanita) jatuh di kereta } \\
& \text { ada luka-luka yang disebabkan } \\
& \text { oleh kecelakaan' }
\end{aligned}
$$

Kalimat (5a) di atas tidak berterima karena tidak ditemukan konstituen penghubung klausa bebas-klausa bebas yang terdapat pada kalimat tersebut. Pada kalimat (5a) seharusnya dibutuhkan kehadiran konjungsi koordinatif shi sebagai pengikat kedua klausa yang terdapat pada konstruksi tersebut.

\section{Konjungsi Koordinatif Menandai "Pertentangan"}

Di dalam bahasa Jepang juga ditemukan konjungsi koordinatif yang menandai hubungan pertentangan. Konjungsi koordinatif yang menandai hubungan pertentangan disebut juga dengan istilah kontradiktif. Dikatakan konstradiktif karena antara satuan lingual yang dihubungkan oleh konjungsi jenis ini itu bertentangan. Di dalam penelitian ini ditemukan bahwa konstituen $g a$ merupakan bentuk konjungsi koordinatif yang meanandai hubungan pertentangan di dalam bahasa Jepang. 
Konstituen $g a$ dapat dikategorikan sebagai case marking atau penanda kasus dan juga dapat dikategorikan sebagai konjungsi koordinatif. Konstituen $g a$ dikategorikan sebagai konjungsi koordinatif apabila konstituen $g a$ menghubungkan dua buah satuan lingual yang sifatnya setara. Seperti yang ditunjukan oleh data di bawah ini:

（6）木村さん は 二十年 kimurasan wa nijyunen Kimura HON TOP 20 tahun

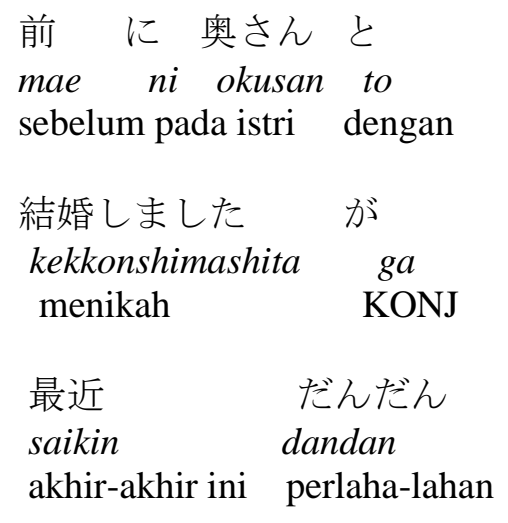

$\begin{array}{lll}\text { 奥さん } & \text { が } & \text { いや } \\ \text { okusan } & \text { ga } & \text { iya } \\ \text { istri } & \text { FOC } & \text { benci } \\ & & \\ \text { になり } & \text { ました。 } \\ \text { ninari } & \text { mashita. } \\ \text { menjadi } & \text { LAMP }\end{array}$

'Tuan Kimura dua puluh tahun yang lalu menikah dengan istrinya, tetapi akhir-akhir ini perlahan-lahan menjadi benci kepadanya'.

Dilihat dari fungsi atau tugas konjungsi, berdasarkan data (6) di atas konjungsi koordinatif $g a$ berfungsi sebagai penghubung satuan lingual berupa klausa. Data (6) di atas terdiri atas dua buah klausa. Kedua klausa yang terdapat pada data (6) merupakan klausa bebas karena masing-masing klausa berpotensi menjadi kalimat apabila konjungsi ga dilesapkan. Klausa pertama data (6) di atas terdiri atas unsur inti berupa subjek dan predikat. Unsur predikatif pada klausa pertama dan klausa kedua terdiri atas verba. Pada klausa pertama yang menjadi predikat yaitu kekonshimashita 'menikah', sementara itu yang menjadi predikat pada klausa kedua adalah iyaninarimashita 'menjadi benci'.

Adapun yang menajadi subjek pada klaua pertama data (6) di atas adalah Kimura. Sedangkan pada klausa kedua tidak ditemukan adanya subjek. Pada klausa kedua data (6) di atas terjadi penghilangan subjek karena subjek pada klausa pertama dengan subjek pada klausa kedua adalah sama yaitu Kimura. Penghilangn subjek di dalam sebuah konstruksi juga dinamakan dengan ellipsis. Elispsis bertujuan untuk menghindari pengulangan munculnya unsur yang sama.

Berdasarkan letak atau posisi strukturalnya, konjungsi ga berada di antara kedua satuan lingual yang dihubungkan. Seperti yang terdapat pada data (6), konjungsi koordinatif ga berada di antara klausa pertama dengan klausa kedua. Apabila digambarkan maka letak struktural konjungsi koordinatif $g a$ berdasarkan data (6) di atas yaitu A co B. Yang mana $\mathbf{A}$ adalah klausa pertama dan B adalah klausa kedau pada data (6) di atas. Konjungsi koordinatif yang menghubungkan kedua klausa pada data (6) di atas di simbolkan dengn co. Letak struktural konjungsi koordinataif $g a$ adalah tegar. Apabila posisi ini dirubah maka kalimat majemuk setara yang terdapat pada data (6) di atas tidak berterima secara gramatikal. Seperti kalimat (6a) di bawah ini:

$$
\begin{aligned}
& \text { (6a) * が木村 さん は 二十年 } \\
& \text { ga kimura san wa nijyunen } \\
& \text { KONJ Kimura HON TOP } 20 \text { tahun } \\
& \text { 前 に 奥さん と } \\
& \text { mae ni okusan to } \\
& \text { sebelum pada istri dengan } \\
& \text { 結婚しました } \\
& \text { kekkonshimashita menikah }
\end{aligned}
$$




$\begin{array}{ll}\text { 最近 } & \text { だんだん } \\ \text { saikin } & \text { dandan } \\ \text { akhir-akhir ini } & \text { perlaha-lahan }\end{array}$

$\begin{array}{lll}\text { 奥さん } & \text { が } & \text { いや } \\ \text { okusan } & \text { ga } & \text { iya } \\ \text { istri } & \text { FOC } & \text { benci } \\ & & \\ \text { になり } & \text { ました。 } \\ \text { ninari } & \text { mashita. } \\ \text { menjadi } & \text { LAMP }\end{array}$

'Tuan Kimura dua puluh tahun yang lalu menikah dengan istrinya, akhir-akhir ini perlahan-lahan menjadi benci kepadanya'.

Kalimat (6a) di atas tidak berterima karena knjungsi koordinatif ga pada kalimat tersebut tidak berfungsi sebagaimana mestinnya. Pada kalimat (6a) di atas konjungsi koordinatif $g a$ terlihat atau ditemukan berada di awal klausa pertama. Seharusnnya letak struktural konjungsi koordinatif $g a$ berada di antara klausa pertama dengan klausa kedua bukan berada di awal atau mengawali klausa pertama. Konjungsi koordinatif ga berfungsi apabila terletak di antara klausa kimura san wa nijyunen mae ni okusan to kekkonshimashita 'tuan Kimura dua puluh tahun yang lalu menikah dengan istri' dengan klausa saikin dandan okusan ga iya ninari mashita ', akhir-akhir ini perlahan-lahan menjadi benci kepadannya'.

Seperti yang sudah disebutkan sebelumnya bahwasanya konjungsi koordinatif $g a$ menadai suatu hubungan yang siftnya kontradiktif. Kontradiktif yang dimaksudkan yaitu antara klausa pertama dan klausa kedua data (6) di atas saling bertentangan maknanya. Konjungsi koordinatif ga mempertentangkan makna klausa kimura san wa nijyunen mae ni okusan to kekkonshimashita 'tuan Kimura dua puluh tahun yang lalu menikah dengan istri' dengan klausa saikin dandan okusan ga iya ninari mashita ', akhir-akhir ini perlahan-lahan menjadi benci kepadannya'. Konjungsi koordinatif $g a$ hanya mampu mengikat dua satuan lingual atau dua klausa saja. Kedua buah klausa yang diikat atau dihubungkan secara koordinatif pada data (6) di atas memiliki subjek yang sama seperti yang sudah disebutkan sebelumnnya.

Konjungsi koordinatif ga wajib hadir di dalam konstruksi kalimat majemuk setara untuk menghubungkan klausa klausa yang terdapat di dalam konstrukksi tersebut. Seperti yang ditunjukan oleh data (6) di atas, konjungsi ga menghubungkan dua buah klausa bebas sehingga membentuk kalimat majemuk setara yang hubungannya bersifat hipotaktis karena terdapat konjungsi koordinatif di dalamnya. Jika konjungis ga yang terdapat pada data (6) dilesapkan maka kalimat menjadi tidak berterima secara gramatikal.

(6b) *木村さん は 二十年

kimura san wa nijyunen

Kimura HON TOP 20 tahun

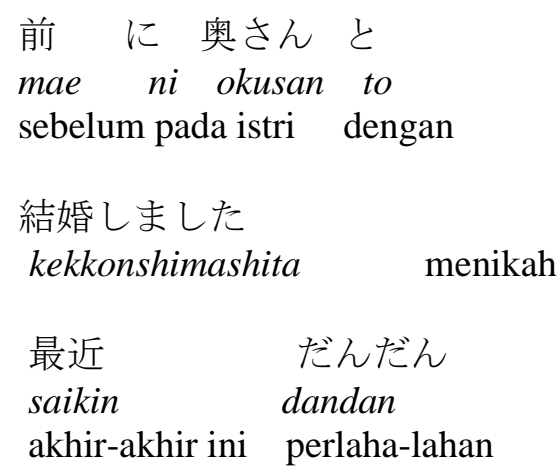

$\begin{array}{lll}\text { 奥さん } & \text { が } & \text { いや } \\ \text { okusan } & \text { ga } & \text { iya } \\ \text { istri } & \text { FOC } & \text { benci } \\ & & \\ \text { になり } & \text { ました。 } \\ \text { ninari } & \text { mashita. } \\ \text { menjadi } & \text { LAMP }\end{array}$

'Tuan Kimura dua puluh tahun yang lalu menikah dengan istrinya, akhir-akhir ini perlahan-lahan menjadi benci kepadanya' 
Kalimat (6b) di atas tidak berterima secara gramatikal karena konjungsi koordinatif ga yang seharusnnya berfungsi sebagai penghubung klausa-klausa yang terdapat pada kalimat tersebut dilesapkan. Karena konjungsi kordinatif ga dilesapkan konstruksi kalimat majemuk setara tidak terbentuk dan makna pertentangan yang terdapat pada kalimat data (6) tidak ditemukan pada kalimat (6b). Karena pentingnnya kehadiran konjungsi koordinatif ga pada konstruksi di atas maka dapat dikatakan bahwa konjungsi koordinatif ga merupakan unusur yang kehadiranya bersifat wajib.

Tabel 1: Ciri gramatikal Konjungsi Koordinatif bahasa Jepang

\begin{tabular}{|c|c|c|c|c|}
\hline \multirow{2}{*}{$\begin{array}{l}\text { Ben } \\
\text { tuk }\end{array}$} & \multirow{2}{*}{$\begin{array}{c}\text { Mak } \\
\text { na }\end{array}$} & \multicolumn{3}{|c|}{$\begin{array}{c}\text { Ciri Sintaksis Konjungsi } \\
\text { Koordinatif }\end{array}$} \\
\hline & & Tugas & Letak & Sifat \\
\hline to & Dan & $\begin{array}{l}\text { Menghu } \\
\text { bungkan } \\
\text { unit } \\
\text { lingual; } \\
\text { Noun } \\
\text { lister }\end{array}$ & $\begin{array}{c}\text { Antara } \\
\text { unit } \\
\text { lingual } \\
\text { yang } \\
\text { dihubung } \\
\text { kan }\end{array}$ & Wajib \\
\hline$y a$ & Dan & $\begin{array}{c}\text { Menghu } \\
\text { bungkan } \\
\text { unit } \\
\text { lingual; } \\
\text { Represent } \\
\text { atif }\end{array}$ & $\begin{array}{c}\text { Antara } \\
\text { unit } \\
\text { lingual } \\
\text { yang } \\
\text { dihubung } \\
\text { kan }\end{array}$ & $\begin{array}{l}\text { Wajib, } \\
\text { tidak } \\
\text { dapat } \\
\text { dilesap } \\
\text { kan. }\end{array}$ \\
\hline$s h i$ & Dan & $\begin{array}{c}\text { Menghu } \\
\text { bungkan } \\
\text { atau } \\
\text { mengikat } \\
\text { unit } \\
\text { lingual } \\
\text { berupa } \\
\text { klausa }\end{array}$ & $\begin{array}{c}\text { Antara } \\
\text { unit yang } \\
\text { dihubung } \\
\text { kan }\end{array}$ & $\begin{array}{l}\text { Wajib, } \\
\text { tidak } \\
\text { dapat } \\
\text { dilesapk } \\
\text { an. }\end{array}$ \\
\hline$g a$ & $\begin{array}{l}\text { Tetap } \\
\text { i }\end{array}$ & $\begin{array}{l}\text { Menghu } \\
\text { bungkan } \\
\text { unit } \\
\text { lingual } \\
\text { berupa } \\
\text { klausa }\end{array}$ & $\begin{array}{c}\text { Antara } \\
\text { unit yang } \\
\text { dihubung } \\
\text { kan. }\end{array}$ & Wajib. \\
\hline
\end{tabular}

\section{Kesimpulan}

Konjungsi yang menghubungkan satuan lingual yan setara kedudukannya dinamakan dengan konjungsi koordinatif. Konjungsi koordinatif dapat menandai hubungan aditif, alternatif dan hubungan kontradiktif.

Berdasarkan analisis data di dalam penelitian ini konjungsi koordinatif yang menandai hubungan aditif di dalam bahasa Jepang yaitu ditemukan konjungsi to. Konstituen to mampu menghubungkan unit lingual di dalam suatu konstruksi gramatikal. Unit lingual yang dapat dihubungkan oleh konjungsi koordinatif to yaitu nomina dengan nomina. Sementara itu konjungsi koordinatif yang menandai hubungan aditif lainya yang ditemukan dalam penelitian ini yaitu konjungsi shi dan konjungsi ya. Konjungsi shi mampu menghubungkan unit lingual berupa klausa di dalam konstruksi kalimat majemuk setara. Sedangkan konjungsi ya sama dengan konjungsi to mampu menghubungkan unit lingual berupa kata. Sementara itu, konjungsi koordinatif $g a$ merupakan konjungsi koordinatif yang menandai hubungan kontradiktif. Konjungsi kontradiktif $g a$ menghubungkan klausa dengan klausa yang kedudukannya setara. Berdasarkan bentuknnya, konjungsi to, ya, dan $g a$ berasal dari partikel. Sedangkan konjungsi koordinatif shi adalah afiks dan selalu menempel pada bentuk lainnya yaitu unsur predikatif.

Konjungsi koordinatif to selain berperan sebagai penghubun satuan lingual berupa kata, juga dapat bertugas sebagai noun lister yaitu menjajarkan bebebrapa nomina di dalam konstruksi.

Berdasarkan letak strukturalnnya, konjungsi koordinatif to, $y a, g a$, dan shi berada di antara unsur ynag digabungkan. Letak struktural keempat konjungsi koordinatif bahasa Jepang tersebut tidak dapat dimutasikan menjadi di awal atupun di akhir sehingga dikatakan bahwa letak struktural konjungsi koordinatif to, $y a$, ga dan shi di dalam bahasa Jepang bersifat tegar. Sementara itu untuk sifat kehadirannya di dalam konstruksi, kehadiran konjungsi koordinatif to, konjungsi $y a$, konjungsi $g a$ dan konjungsi 
shi tidak dapat dilesapkan atau bersifat wajib.

\section{Daftar Pustaka}

Afifuddin, Beni Ahmad Saebani. Metodologi Penelitian Kualitatif. Bandung: CV. Pustaka Setia, 2009.

Al-Buqori. "Setsuzokushi Aruiwa Dan Soretomo Dalam Bahasa Jepang." Andalas University, 2014.

Alwi, dkk. Tata Bahasa Baku Indonesia. Jakarta: Balai Pustaka, 1998.

Djajasudarma, T. Fatimah. Metode Linguistik: Ancangan Metode Penelitian Dan Kajian. Bandung: PT. Refika Aditama, 2006.

Eugene A Nida. Morphology: The Descriptive Analysis of Word. Ann Arbor: The University of Michigan Press, 1963.

Harimurti Kridalaksana. "Kelas Kata Dalam Bahasa Indonesia." Jakarta: Gramedia Pustaka, 2008.

Ismail. "Konjungsi Tameni Dan Youni Dalam Bahasa Jepang (Kajian Semantik)." Andalas University, 2009.

J.J, Song. "Linguistic Typology: Morphology and Syntac." England: Pearson Education Limited, 2001.

Muslich, Masnur. Garis-Garis Besar Tata Bahasa Baku Bahasa Indonesia. Bandung: PT. Refika Aditama, 2010.

Nugraha, Oktavian Aditya, Abdul Ngalim, and Yakub Nasucha.
"Penggunaan Konjungsi Dalam Bahasa Tulis Dan Lisan Oleh Siswa Kelas Lima Bakti Pandeyan 01 Sukoharjo." Jurnal Penelitian Humaniora 16, no. 2 (Agustus 2015): 43-50.

Purwiati, Ida Ayu Mirah. "Konjungsi Subodinatif Dalam Teks Buku Pelajaran SLTA: Analisis Bentuk , Distribusi, Dan Makna." Aksara 27, no. 2 (Desember 2015): 13350 .

Ratnawati. "No TitleKonjungsi Dan Klausa Subordinat Dalam Bahasa Jawa." Universitas Indonesia, 1994.

Sari, Cici Puspita. "Konjungsi Koordinatif Aditif Bahasa Sunda." EJurnal Mahasiswa Universitas Padjajaran 1, no. 1 (2012).

Setiana, Soni Mulyawan. "Fungsi Dan Penggunaan Setsuzokushi (Sorede, Sokode, Dan Suruto)." Majalah Ilmiah UNIKOM 10, no. 2 (2012).

Sophen, Tymothi (Ed). Typologi and Sintactic Description: Volume 1, Clause Structure. New York: Cambridge University Press, 2007.

Sudaryanto. Metode Dan Teknik Analisis Bahasa: Pengantar Penelitian Wahana Kebudayaan Secara Linguistis. Yogyakarta: Sanata Dharma University Press, 2015.

Tri Mastoyo Jati Kesuma. "Pengantar (Metode) Penelitian Bahasa." Yogyakarta: Crasvatibooks, 2007. 